\title{
Mahogany Shoot Borer, Hypsipyla grandella (Zeller) (Insecta: Lepidoptera: Pyralidae: Phycitinae) ${ }^{1}$
}

\section{F. W. Howard and Michael A. Merida ${ }^{2}$ \\ Introduction}

The mahogany shoot borer, Hypsipyla grandella (Zeller), bores in twigs and seed capsules of trees in the mahogany family (Meliaceae), especially mahogany species (Swietenia spp.) and cedro, known also as Spanish-cedar and tropical-cedar (Cedrela spp.). It is an important economic pest and has been the subject of concerted research efforts in several tropical countries. It is the only species of Hypsipyla in Florida, where it is a pest of West Indies mahogany (Swietenia mahagoni Jacquin), a native tree that is frequently planted as an ornamental or shade tree in southern Florida.

Hypsipyla robusta (Moore) and closely related species in Madagascar and Africa play similar roles as important shoot borers of meliaceous trees in tropical regions of the Eastern Hemisphere.

Hypsipyla robusta as currently understood is a species complex and its taxonomy is being resolved (Marianne Horak, personal communication). Hypsipyla robusta and perhaps other species of this complex have been variously referred to as the toona fruit and shoot borer, cedar tip moth, cedar shoot caterpillar, and also in some countries as the mahogany shoot borer. In this article, the name mahogany shoot borer will refer to the American species, i.e., H. grandella.

Nine additional species of Hypsipyla have been described. All are tropical (three in the Americas and six in the Eastern Hemisphere). The distribution of each of these is limited, they are not important economic pests, and little is known about their biology (Horak 2001). Recent reviews of Hypsipyla shoot borers include Newton et al. (1993) and Griffiths (2001). Books on mahogany with discussions of insects associated with them include Lamb (1966) and Mayhew and Newton (1998). Thirty-six papers on these insects were recently published in the proceedings of a workshop entitled Hypsipyla shoot borers in Meliaceae (Floyd and Hauxwell 2001), which is online at http://aciar.gov.au/web.nsf/doc/JFRN-5J472Q.

\section{Distribution}

The distribution of the mahogany shoot borer coincides with that of its principal host plant species, mahoganies and cedros, i.e., southern Florida, most of the West Indies, Sinaloa and southward in Mexico,

1. This document is EENY-336, one of a series of Featured Creatures from the Entomology and Nematology Department, Florida Cooperative Extension Service, Institute of Food and Agricultural Sciences, University of Florida. Published: December 2004. Revised: January 2005. This document is also available on Featured Creatures Website at http://creatures.ifas.ufl.edu. Please visit the EDIS Website at http://edis.ifas.ufl.edu. 2. F. W. Howard and Michael A. Merida, Department of Entomology and Nematology, University of Florida, Gainesville, FL.

The Institute of Food and Agricultural Sciences (IFAS) is an Equal Opportunity Institution authorized to provide research, educational information and other services only to individuals and institutions that function with non-discrimination with respect to race, creed, color, religion, age, disability, sex, sexual orientation, marital status, national origin, political opinions or affiliations. U.S. Department of Agriculture, Cooperative Extension Service, University of Florida, IFAS, Florida A. \& M. University Cooperative Extension Program, and Boards of County Commissioners Cooperating. Larry Arrington, Dean 
Central America, and South America except Chile (Griffiths 2001).

\section{Description}

From Ramirez Sanchez (1964), Becker (1976), Solomon (1995):

Adults: The adults of $H$. grandella are brownish to grayish-brown in color with a wingspan measuring about 23 to $45 \mathrm{~mm}$. The forewings are gray to brown with shades of dull rust red on the lower portion of the wing. The middle to outer areas of the forewings appear dusted with whitish scales with black dots toward the wing tips. Wing veins are distinctively overlaid with black. The hind wings are white to hyaline with dark colored margins.

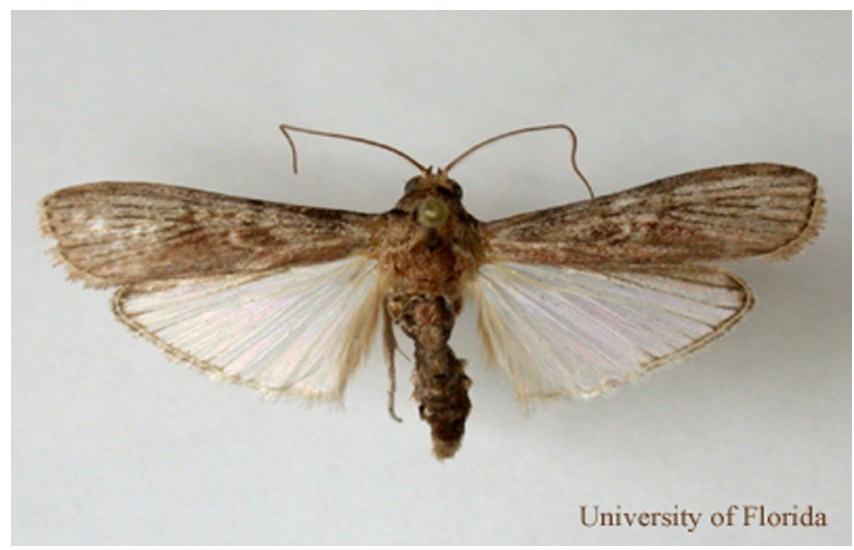

Figure 1. Mahogany shoot borer, Hypsipyla grandella (Zeller), adult moth, pinned specimen. Credits: L.J. Buss, University of Florida

Eggs: The eggs of the mahogany shoot borer are oval and flattened and approximately $0.50 \mathrm{~mm}$ in width and $0.98 \mathrm{~mm}$ in length. The color of the eggs changes from white to red within the first 12 hours after oviposition.

Larvae: The body of the early instar larva is tan to white in color, becoming bluish in later instars. The head capsule is brown. Mature larvae are about $25 \mathrm{~mm}$ long.

Pupa: The pupae of $H$. grandella are brownish-black in color and enclosed in a silken cocoon.

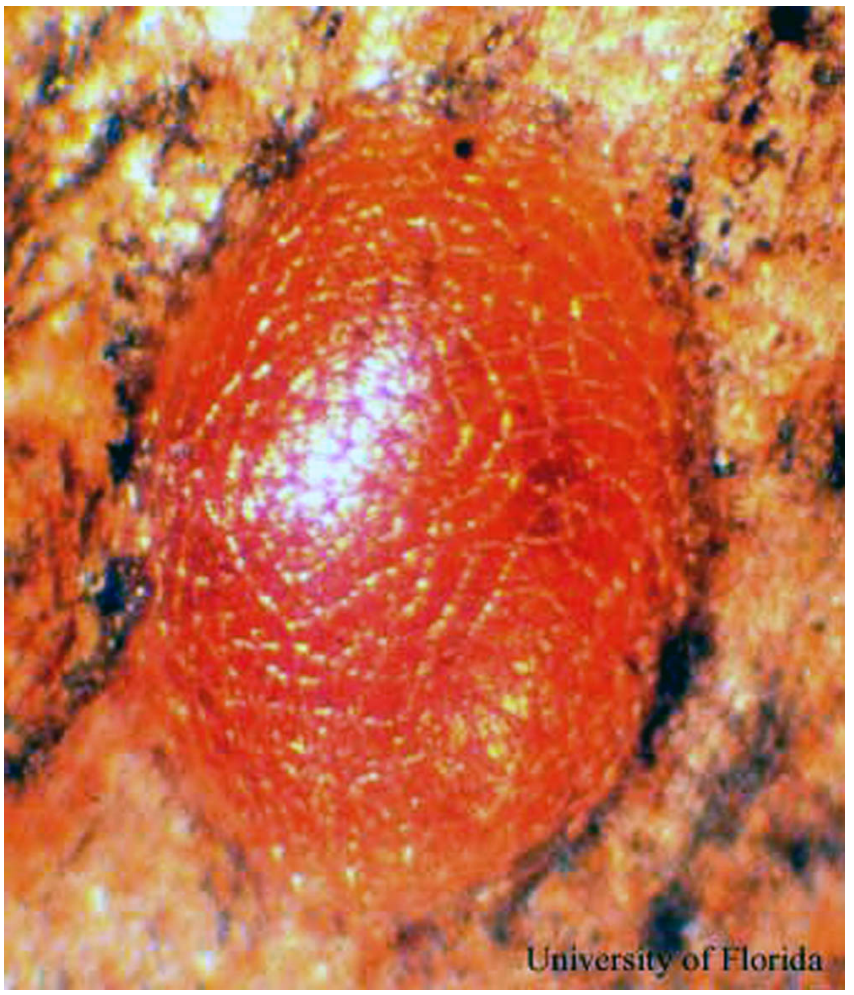

Figure 2. Mahogany shoot borer, Hypsipyla grandella (Zeller), egg. Credits: J.V. DeFilippis, University of Florida

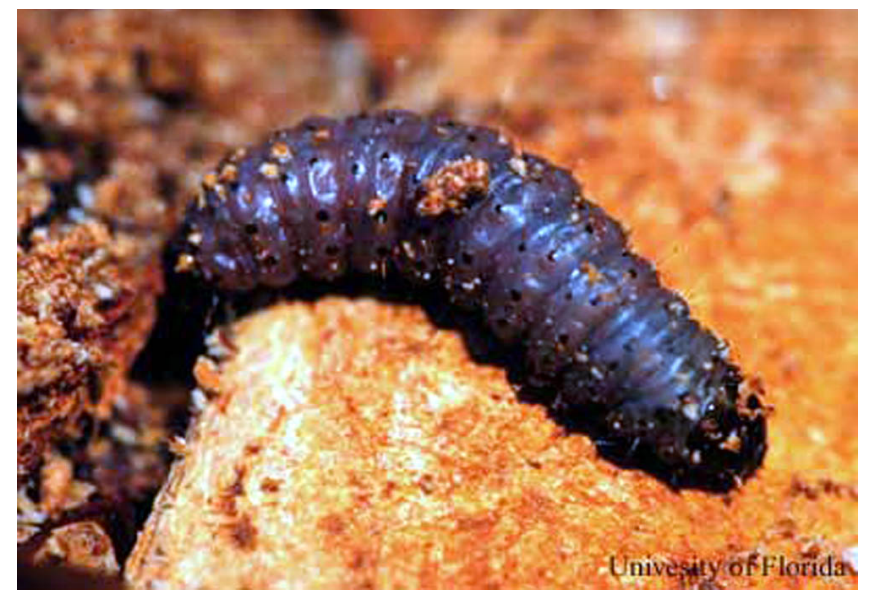

Figure 3. Mahogany shoot borer, Hypsipyla grandella (Zeller), larva. Credits: F.W. Howard, University of Florida

\section{Biology}

The adult moths are nocturnal and live seven to eight days (Holsten 1976). The eggs are deposited during the early morning hours on leaf scars, new shoots, leaf veins and fruits. They are generally laid singly but may sometimes be aggregated into clusters of three to four eggs in or near leaf-axils. A female may lay about 300 eggs, but typically lays no more than a few eggs per tree (Solomon 1995). The eggs incubate for three to five days, depending on ambient 
temperature (Grijpma 1974). Larval development takes place typically through six (range five to seven) instars (Entwistle 1967). In studies of the development time of mahogany shoot borer larvae feeding on fresh cedros foliage at constant temperatures, the duration of the larval stage varied between $30\left(30^{\circ} \mathrm{C}\right)$ and 104 days $\left(15^{\circ} \mathrm{C}\right)$ (Taveras et al. 2004a). In the field, the total development time including the larval, prepupal, and pupal stages, is usually one to two months and may be extended if the larvae undergo diapause (Griffiths 2001). Recently emerged first instar larvae may begin feeding on leaf or twig surfaces, then bore into shoots or seed capsules. Larvae that bore in shoots produce a tunnel of several centimeters in length. The hollow shoot dies and buckles, and the leaves of this twig die. A mass of reddish-brown frass intertwined with the insect's silk protrudes from the tunnel entrance. It can be determined whether a larva is actively boring in a twig by the appearance of the expended frass, as this is compact and relatively light colored when fresh, becoming darker and disintegrated after the larva is no longer feeding (Howard 1991). By splitting an infested twig the larva or pupa can be examined.

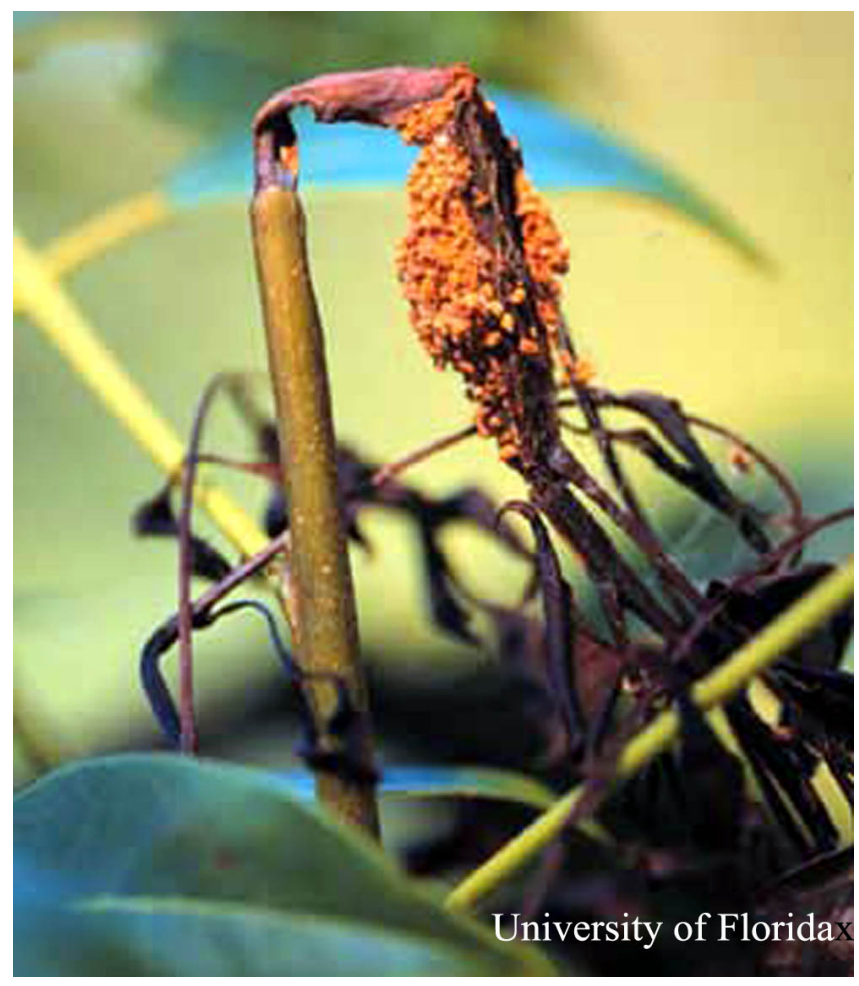

Figure 4. Damage to mahogany shoot by mahogany shoot borer, Hypsipyla grandella (Zeller). Credits: F.W. Howard, University of Florida

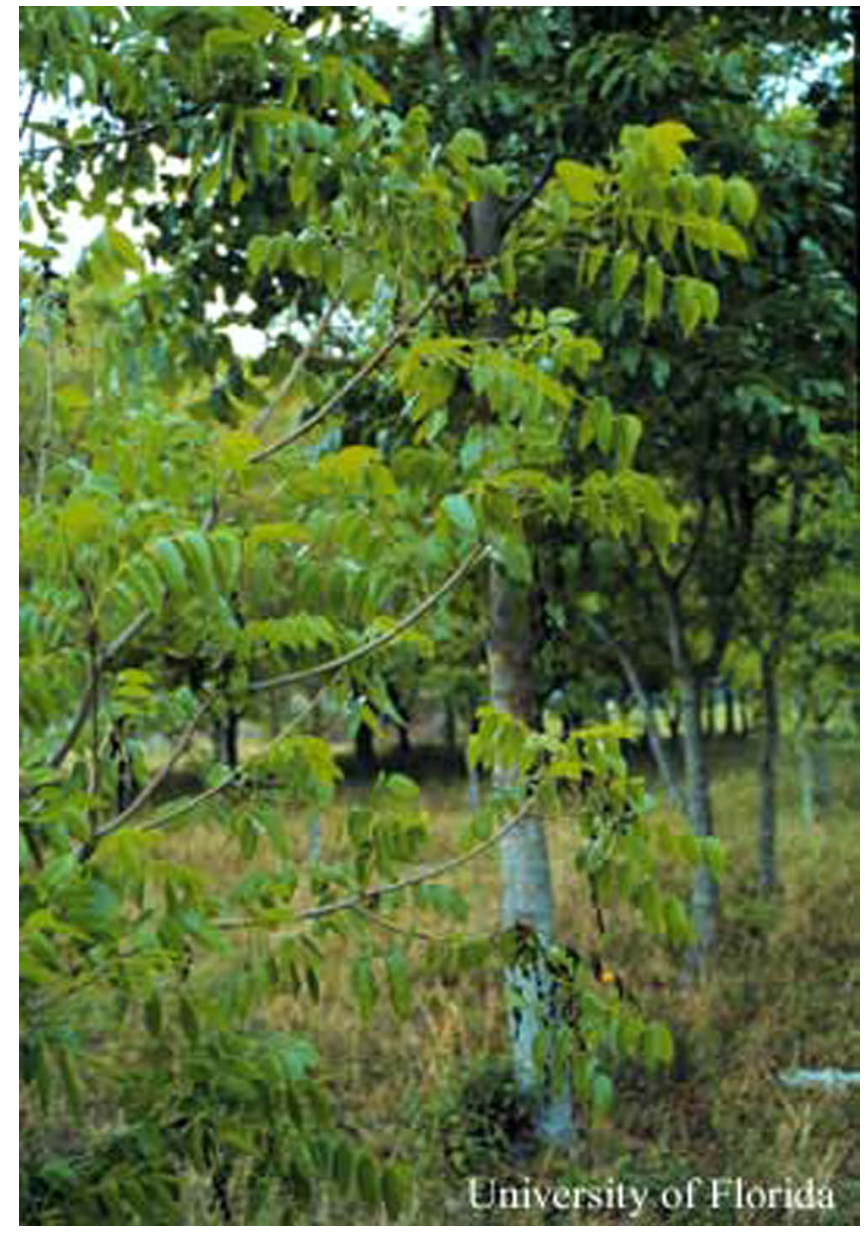

Figure 5. Young West Indies mahogany tree with several shoots damaged by mahogany shoot borer, Hypsipyla grandella (Zeller). Credits: F.W. Howard, University of Florida

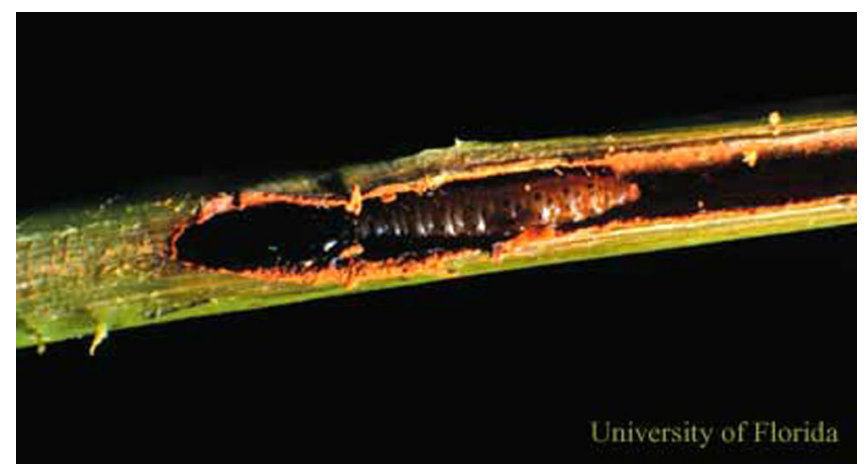

Figure 6. Twig of West Indies mahogany split to reveal larva of mahogany shoot borer, Hypsipyla grandella (Zeller). Credits: Jim DeFilippis, University of Florida

Mahogany shoot borers attack new shoots and are seldom seen attacking hardened-off shoots. In southern Florida, where the flush of new growth of West Indies mahogany takes place from April to June (Howard and Solis 1989), mahogany shoot borers attack shoots from early spring to mid-summer, with 
pronounced peaks in May (Howard 1991). In the tropics, mahogany shoot borers are active all year (Taveras et al. 2004b), with high shoot borer activity typically occurring with growth flushes of mahoganies subsequent to periods of high rainfall. Population increases in spring have been observed in some studies in the tropics, i.e., at the beginning of the rainy season (Roovers 1971, Bauer 1987).

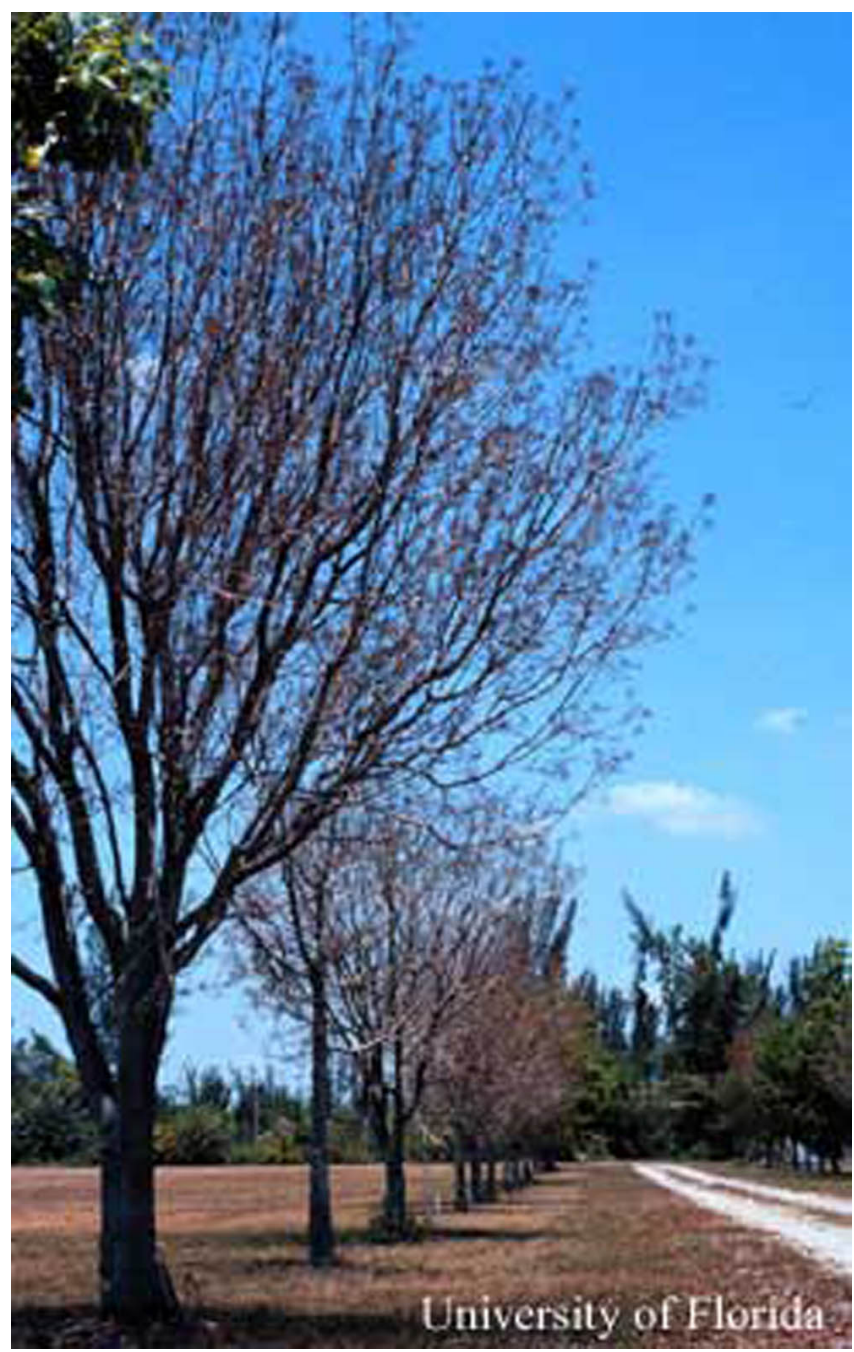

Figure 7. West Indies mahogany, Swietenia mahagoni, undergoing spring flush. Credits: F.W. Howard., University of Florida

Mahogany shoot borers also attack seed capsules of mahoganies and cedros. According to observations of mahogany shoot borers on West Indies mahoganies in southern Florida, they seldom bore into the hard valves of the seed capsules, but enter between them once the capsules have dehisced. There they hollow out seeds, after which they bore into the capsule's core, where they sometimes pupate. In Florida, mahogany shoot borer attack on seed capsules of West Indies mahogany is mostly limited to the period during which the capsules dehisce, i.e., in spring prior to and simultaneous to the new shoot flush (Howard and Gilblin-Davis 1997). The pupal stage takes place inside the hollowed twig or in the seed capsule, or in the leaf litter or soil under host trees. Average duration of the pupae stage is 10 days (Ramirez Sanchez 1964).

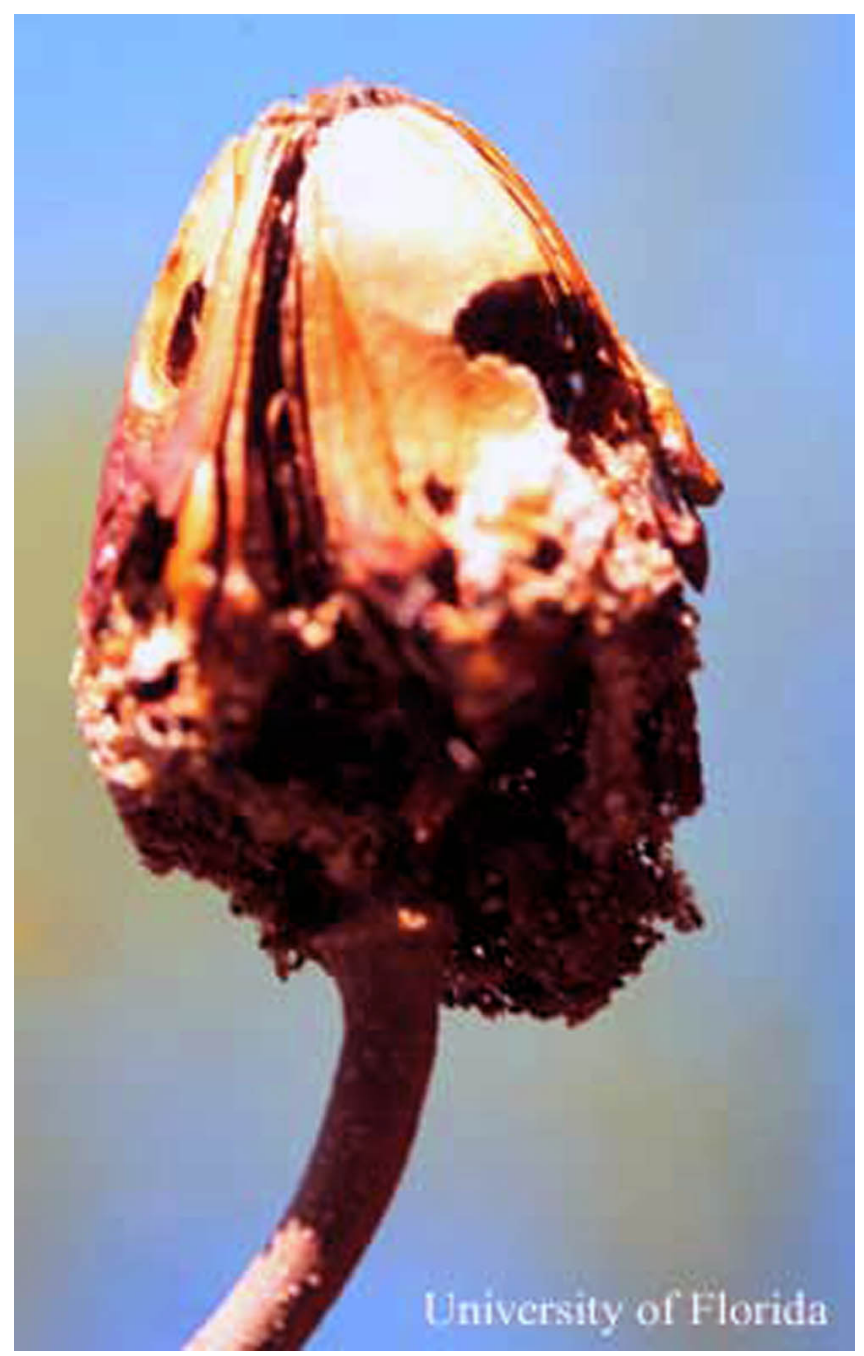

Figure 8. West Indies mahogany, Swietenia mahagoni, seed capsule damaged by mahogany shoot borer, Hypsipyla grandella (Zeller). Credits: F.W. Howard., University of Florida

\section{Hosts}

Species of several genera in the botanical family Meliaceae can serve as hosts of the mahogany shoot borer, including Carapa, Cedrela, Guarea, Khaya, Swietenia, and Trichilia (Entwistle 1967, Becker 1976). Most known species are native to the American Tropics, but species exotic to this region 


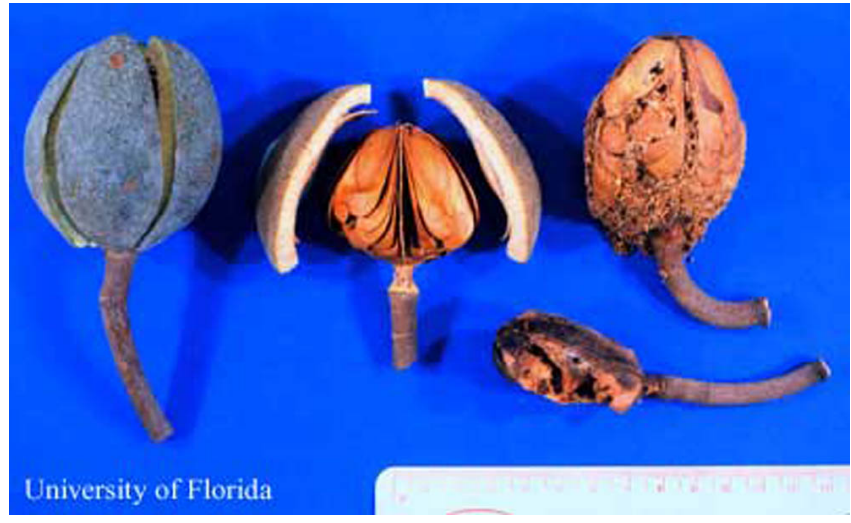

Figure 9. West Indies mahogany, Swietenia mahagoni, seed capsules and their parts damaged by mahogany shoot borer, Hypsipyla grandella (Zeller). Left to Right: Capsule in initial stage of dehiscence, dehisced insect-free capsule, core damaged by larvae, dehisced capsule with larval damage. Credits: F.W. Howard, University of Florida

such as African mahoganies (Khaya spp.) have been attacked when planted in the American Tropics.

Of native host species, Cedrela odorata L., has the widest distribution, occurring on mainland areas of the Americas from northern Mexico through Argentina, and on most of the islands of the West Indies (Cintron 1990). The range of this species more or less coincides with that of the mahogany shoot borer except Cedrela odorata is not native to Florida. There are at least 11 species of Cedrela (Pennington 1981), and the mahogany shoot borer is known to attack at least some of them additional to $C$. odorata (Becker 1976). Cedros are fast growing and are large trees at maturity. Their wood is used locally in numerous ways throughout the American Tropics, and they are planted as shade trees in urban areas of this region, but are present only as occasional specimen trees in Florida.

The vernacular name of the mahogany shoot borer reflects the greater commercial importance of its mahogany hosts. True mahoganies (Swietenia spp.) are native to the American Tropics and some subtropical areas such as Bahamas and southern Florida. The genus includes the following three species (Record and Hess 1943, Lamb 1966, Pennington 1981):

West Indies mahogany (S. mahagoni [Jacquin]), which is native to southern Florida, the Bahamas, and the Greater Antilles except Puerto Rico. This is one of the most popular shade trees in urban areas of

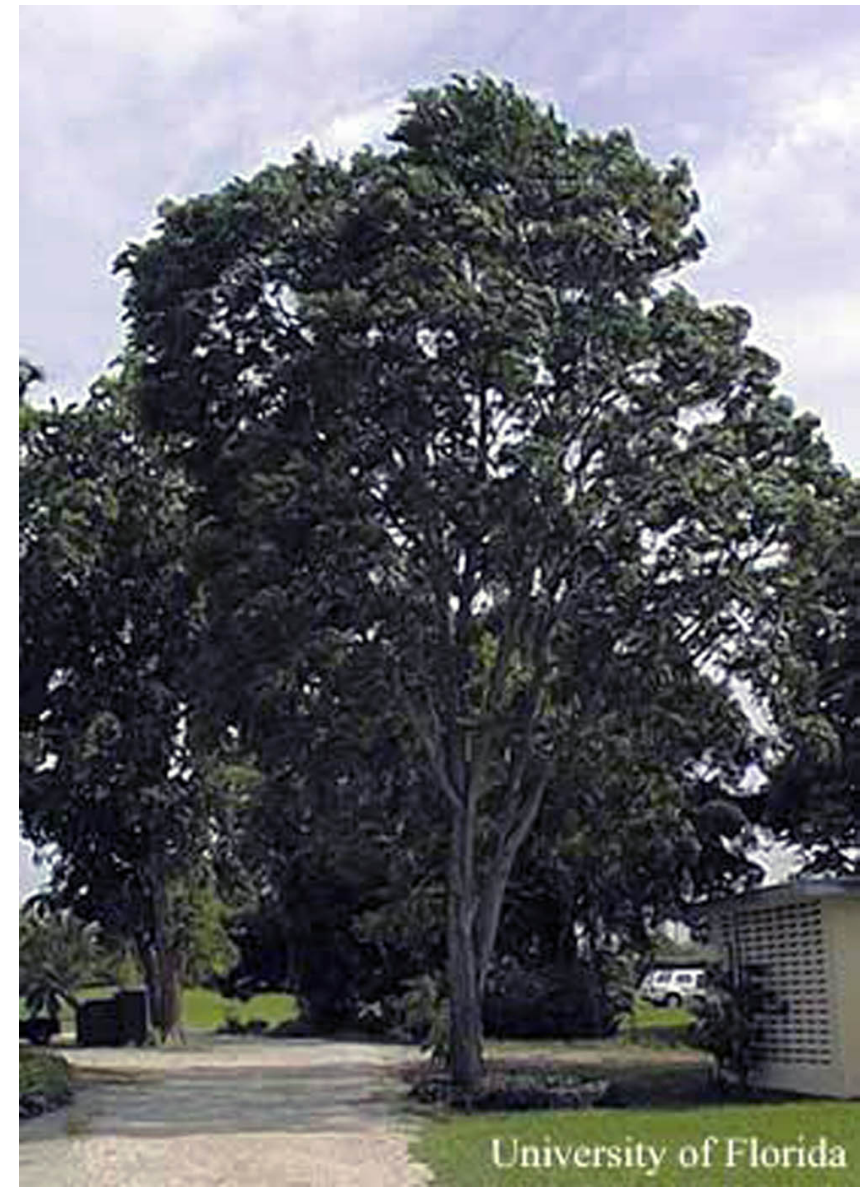

Figure 10. Tropical-cedar, Cedrela odorata. Credits: F.W. Howard., University of Florida

southern Florida, and is a component of natural forests of areas such as the Everglades and the Florida Keys. It is the only large meliaceous tree that is common in Florida.

Honduras mahogany, or big-leaf mahogany ( $S$. macrophylla King), which is native to mainland Tropical America, occurs in lowland humid regions from about $22^{\circ} \mathrm{N}$ latitude on the Atlantic side of Mexico though Central and South America to about $22^{\circ} \mathrm{S}$ latitude in Bolivia. It is presently the main source of mahogany wood. It is present in Florida only as an occasional specimen tree.

Pacific mahogany (S. humilis Zuccarini) is distributed in a strip along the Pacific coastal areas of Mexico to Costa Rica. In Florida it is a rarely encountered specimen tree.

True mahoganies are perhaps the most important tropical timber trees in the world. Their major use is as cabinet woods. During the Colonial Period in the 


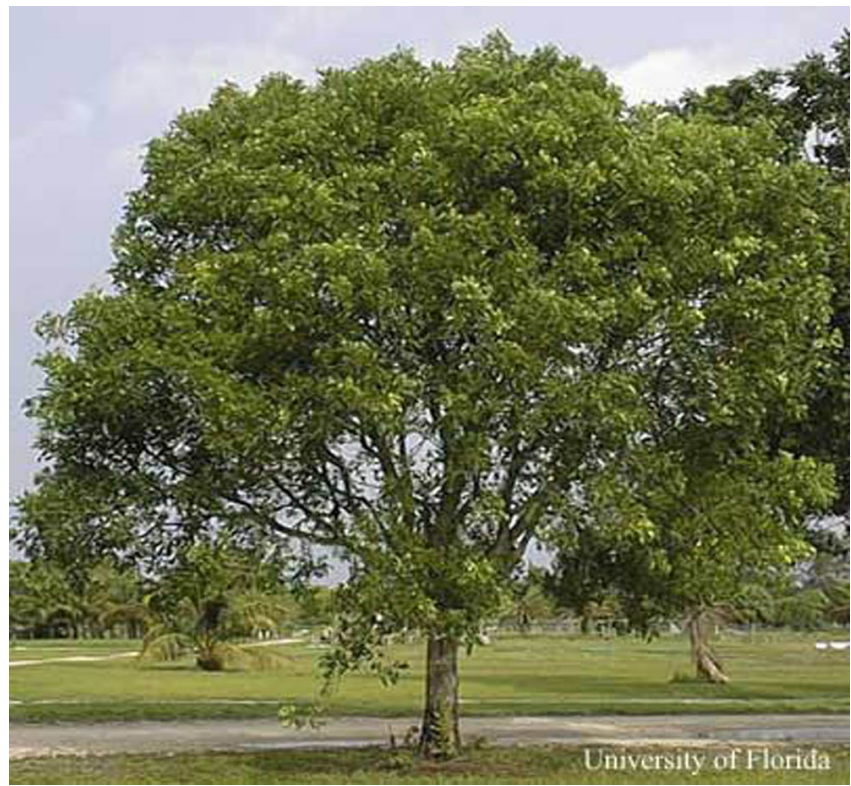

Figure 11. West Indies mahogany, Swietenia mahagoni. Credits: F.W. Howard., University of Florida

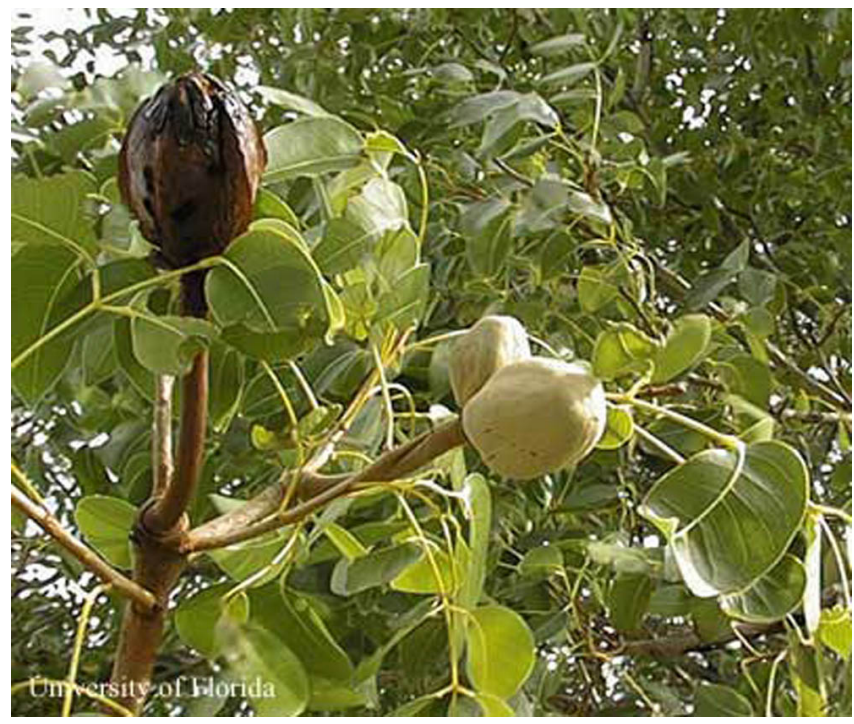

Figure 12. West Indies mahogany, Swietenia mahagoni, foliage and seed capsules. Credits: F.W. Howard., University of Florida

Caribbean Region, West Indies mahogany was extensively logged, after which the more extensively distributed Honduras mahogany on the mainland of the Americas became the major source of mahogany timber.

Some meliaceous tree species that are native to the tropics of the Eastern Hemisphere are attacked by mahogany shoot borer ( $H$. grandella) when grown as exotics in the Americas; in their native ranges they are generally hosts of this insect's Eastern Hemisphere counterpart, $H$. robusta. An example is

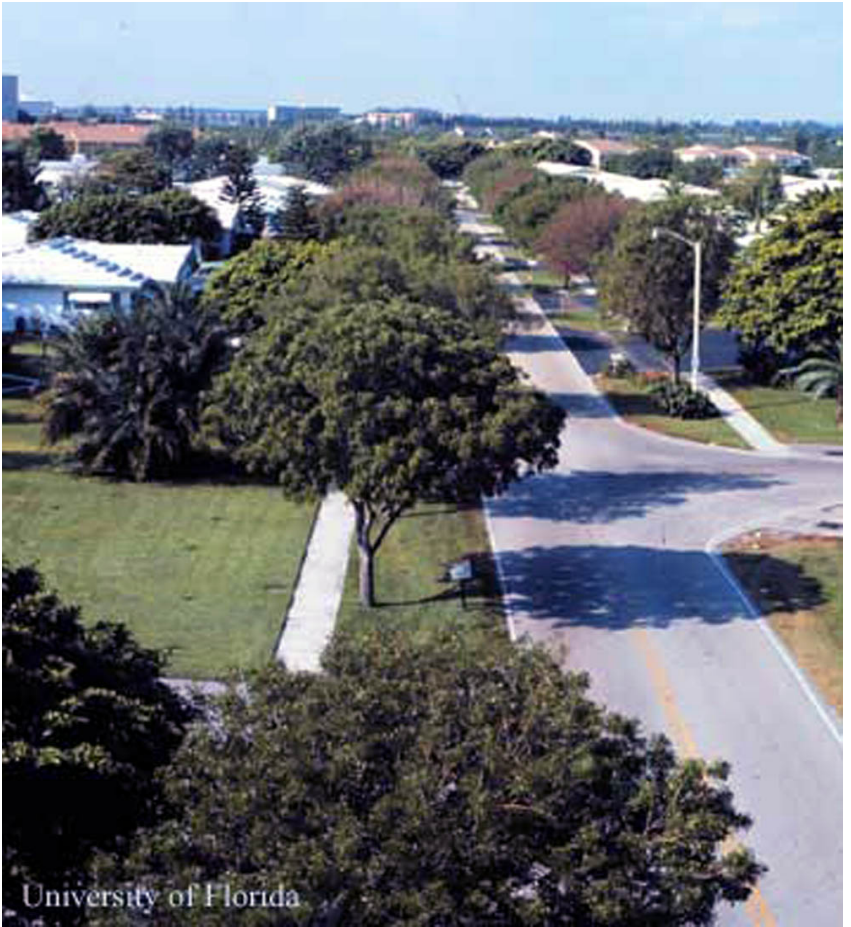

Figure 13. West Indies mahogany, Swietenia mahagoni, as a shade tree in urban area of Florida. Credits: F.W. Howard., University of Florida

Nyasaland (African) mahogany (Khaya nyasica Stapf ex Baker f.) (Entwistle 1967, Becker 1976). On the other hand, Australian red-cedar (Toona ciliata [Roemer]) var. australis, and African mahogany (Khaya ivorensis A. Chevallier), both important meliaceous timber trees of the Eastern Hemisphere tropics that are heavily attacked by $H$. robusta when growing there, were not attacked by $H$. grandella when grown in Costa Rica (Grijpma 1970).

\section{Damage}

Mahogany trees are susceptible to attack when they reach a height of 0.5 meter (Griffiths 2001), although in Florida they are seldom attacked when less than about $1.0 \mathrm{~m}$ tall (Howard, unpublished). The insect's most severe damage to trees occurs when a larva bores into and kills the terminal shoot. A lateral branch grows upward to replace the lost terminal shoot, resulting in a crooked main stem. Also, the damage to the terminal breaks apical dominance, resulting in excessive lateral branching. (Howard and Meerow 1993). Small trees whose terminal shoots are attacked repeatedly in successive years become extremely deformed. 


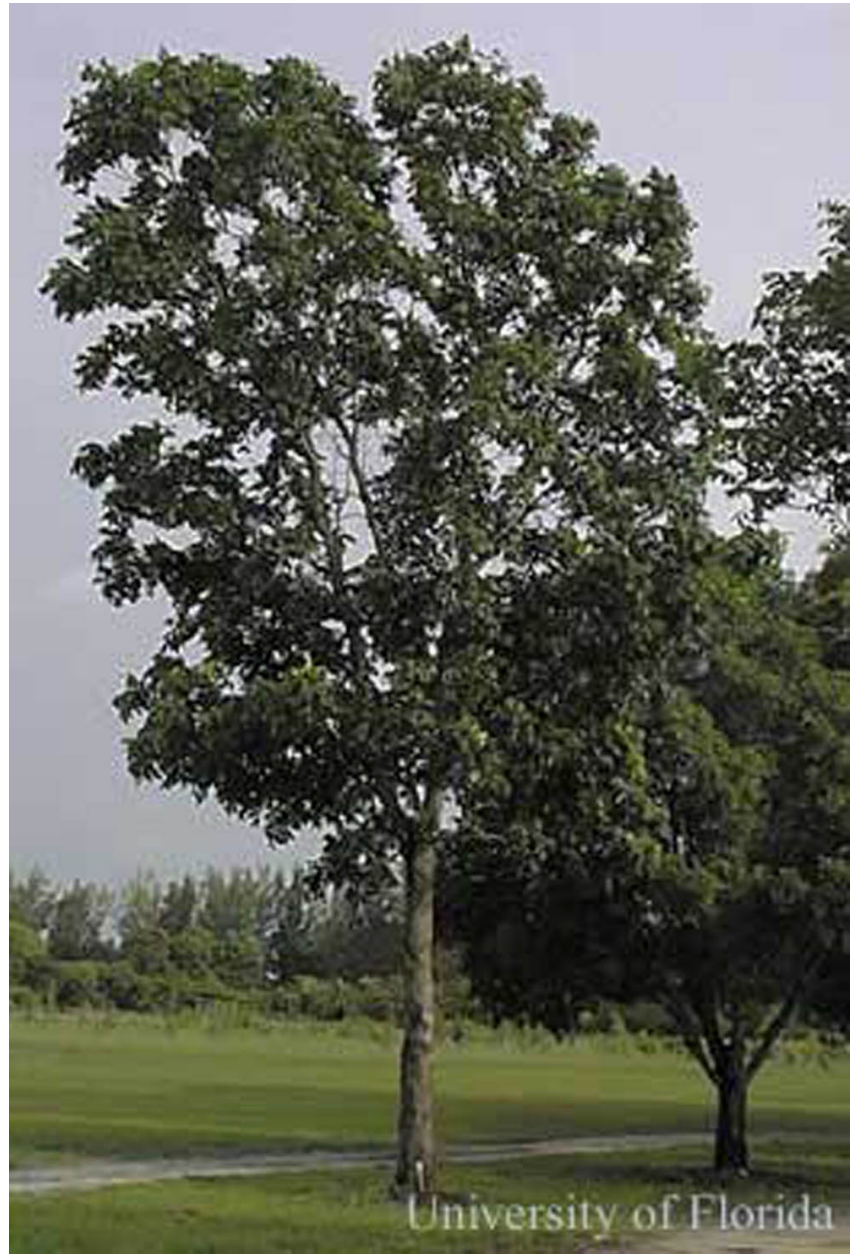

Figure 14. Honduras mahogany, Swietenia macrophylla. Credits: F.W. Howard., University of Florida

Mahogany shoot borer attack reduces the grade and thus the monetary value of young mahoganies grown in nurseries for use as ornamentals, their chief use in Florida (Howard and Meerow 1993). Because attacks ultimately result in a reduction in the number and length of straight, clear logs, mahogany shoot borers are a major pest of mahoganies, cedros, and other meliaceous timber trees grown for timber in the tropics. They attack a higher percentage of trees where mahoganies are grown in plantations than where these trees grow interspersed in natural forests, and this insect has been a major impediment to the establishment of mahogany plantations. Methods of growing mahoganies in plantations as a way of lessening the impact of logging on natural forests are urgently needed (Lamb 1966, Newton et al. 1993, Mayhew and Newton 1998, Floyd and Hauxwell 2001).
Many authors have mentioned the damage to seeds by mahogany shoot borer, e.g., Monte (1933), Tillmanns (1964), and Becker (1976), but this has usually been regarded as unimportant or second in importance to the damage to the shoots. Becker (1976) suggested that seed production is high enough to compensate for losses to the mahogany shoot borer. However, in a study in Florida, mahogany shoot borers attacked up to $100 \%$ of the seed capsules per West Indies mahogany tree and consumed 50 to $96 \%$ of the seeds per capsule. During the same period, only 14 to $22 \%$ of new shoots on the trees were attacked. The impact of this insect on regeneration should be investigated further.

\section{Management}

Research efforts to develop management methods have been much greater for mahogany shoot borer as a pest of timber trees rather than as ornamental or shade trees (Lamb 1966, Grijpma 1974, Newton et al. 1993, Mayhew and Newton 1998, Floyd and Hauxwell 2001). In either situation, this insect is notoriously difficult to control, primarily because although some methods reduce the pest population considerably, even light populations can cause significant damage. In fact, the most important damage of the insect, viz., destruction of the terminal shoot, is the result of a single larva per tree.

In Florida, the mahogany shoot borer is largely a pest of West Indies mahogany in container and field nurseries where these native trees are grown for use as shade trees. Mahoganies established in the landscape are also commonly attacked by mahogany shoot borers, mostly in the spring, but the damage does not noticeably affect growth or aesthetic quality of mature trees. Only a percentage of the growing shoots on a tree are attacked, the damage to the twigs is not conspicuous from a distance, and growth of branches during the summer conceals the damage.

Chemical control. Wylie (2001) reviewed published information on chemical control of Hypsipyla spp. shoot borers, summarizing that after more than eight decades of research in 23 tropical countries there is still no reliable, cost-effective, and environmentally sound chemical control method available to prevent economic damage by these 
insects. He suggested, however, that chemical control of these pests might be applicable to nursery situations. This may be true in Florida, where the mahogany shoot borer attacks twigs mostly in spring, and thus chemical applications can be concentrated during this period.

Because the first instar larva may feed on surface tissues for a brief period before boring into the twig or fruit (Ramirez Sanchez 1964), it is theoretically possible to reduce populations of mahogany shoot borer by topical applications of a pesticide or an antifeedant. In fact, repeated topical applications of azadirachtin (neem seed extract), an insect antifeedant, to young mahogany trees during the principal period of mahogany shoot attack in Florida (April-May) reduced the incidence of damage (Howard 1995), but later a similar experiment was inconclusive (Howard, unpublished). Some contact insecticides that are effective against other twig borers have been field tested to reduce damage by mahogany shoot borer without success. A root drench with imidacloprid prior to the spring season failed to protect mahoganies from shoot borers (Howard, unpublished). However, since imidacloprid is absorbed at different rates by different tree species, the effectiveness of a drench treatment applied earlier in the season should be tested.

Biological control. About 40 species of insects have been identified as natural enemies of the mahogany shoot borer in the Americas (Sands and Murphy 2001). These are, like the mahogany shoot borer itself, native to the region. They undoubtedly are of varying degrees of importance in regulating populations of this insect, but their effect is insufficient to prevent economic damage. Although there has been some interest in such techniques as augmentation of natural enemy populations, biological control of the mahogany shoot borer does not seem a promising option (reviewed by Sands and Murphy 2001). This is primarily because even sparse populations can cause severe economic damage, as explained previously.

Silviculture. Mahoganies growing in natural forests often occur at low densities and mixed with many other species. Under such conditions they are less likely to be attacked by mahogany shoot borers.
This principle has been applied in various silvicultural techniques with varying degrees of success, and research continues in this area (Lamb 1966, Mayhew and Newton 1998, Hauxwell et al. 2001, Grogan et al. 2002). It has long been observed that mahoganies growing in shade tend to be less susceptible, or escape attack by Hypsipyla spp., and recent research on $\mathrm{H}$. robusta indicates that this is because of a physiological difference between trees growing in shade or in the open (Mahroof et al. 2000).

Tree improvement. In testing different provenances of mahoganies and cedros, less damage has been seen in some selections. Research to identify genetic strains of these trees that are resistant or that can overcome shoot borer attack has progressed well (Mayhew and Newton 1998, Watt et al. 2001).

Integrated Pest Management. The conclusions of the participants of an international workshop on Hypsipyla shoot borers in 1996 was that the strategies most promising for management of these pests involved identification and use of resistant genotypes, and planting mahogany and cedro trees in mixed rather than pure stands and under an established canopy. It was also emphasized that vigorous growth of young trees should be promoted by cultural methods in the nursery and in young plantations. Chemical control was seen as a tool for temporarily reducing shoot borer populations in limited areas (Floyd 2001, Floyd and Hauxwell 2001, Speight 2001). These conclusions apply mostly to management of mahoganies and other meliaceous trees grown for timber. Integrated pest management of mahogany shoot borer in nurseries in Florida where mahoganies are grown for use as shade trees should involve methods of reducing pest populations during spring and pruning methods that promote recovery of form of trees that are attacked.

\section{Acknowledgements}

We thank Dr. Carrie Hauxwell, Senior Scientist, Agency for Food and Fibre Sciences, Department of Primary Industries and Fisheries, Brisbane, Australia, for reviewing this article and Dr. Marianne Horak, Taxonomic Specialist in Lepidoptera, Australian National Insect Collection, CSIRO Entomology Canberra, Australia, for information on the taxonomic status of Hypsiypla spp. 


\section{Selected References}

Bauer GP. 1987. Swietenia macrophylla and Swietenia macrophylla X S. mahagoni development and growth: the nursery phase and the establishment phase in line planting in the Caribbean National Forest, Puerto Rico. M.S. Thesis. State University of New York, College of Environmental Science and Forestry, Syracuse, N.Y.

Becker VO. 1976. Microlepidopteros asociados con Carapa, Cedrela, y Swietenia en Costa Rica, pp. 75-101. In Whitemore JL [ed.], Studies on the shootborer, Hypsipyla grandella (Zeller), Lep.:Pyralidae, CATIE Misc. Publ. No. 1. CATIE, Turrialba, Costa Rica.

Cintron BB. 1990. Cedrela odorata L. Cedro hembra, Spanish cedar, pp. 250-257. In Burns RMH, Barbara H [ed.], Silvics of North America 2: Hardwoods. Agricultural Handbook 644. United States Department of Agriculture, Washington, DC.

Entwistle PF. 1967. The current situation on shoot, fruit and collar borers of the Meliaceae., Proceedings of the 9th British Commonwealth Forestry Conference. Commonwealth Forestry Institute, Oxford.

Floyd RB. 2001. General conclusions and research priorities. pp. 183-187. In Floyd RB, Hauxwell C (eds.), International Workshop on Hypsipyla shoot borers in Meliaceae, 20-23 August 1996. ACIAR Proceedings No. 97.

Floyd RB., Hauxwell C. (eds.) 2001. Hypsipyla shoot borers in Meliaceaae. Proceedings of an International Conference held at Kandy, Sri Lanka 20-23 August 1996. ACIAR Proceedings No. 97. Australian Centre for International Agricultural Research, Canberra, Australia.

Griffiths MW. 2001. The biology and ecology of Hypsipyla shoot borers. pp. 74-80. In Floyd RB, Hauxwell C (eds.), International Workshop on Hypsipyla shoot borers in Meliaceae, 20-23 August 1996. ACIAR Proceedings No. 97.

Grijpma P. 1970. Immunity of Toona ciliata M. Roem. var. australis (F. v. M.) DC. and Khaya ivorensis A. Chev. to attacks of Hypsipyla grandella Zeller in Turrialba. Turrialba 20: 85-93.

Grijpma P. 1974. Contributions to an integrated control programme of Hypsipyla grandella (Zeller) in Costa Rica. Landbouwhogeschool te Wageningen., Wageningen, Netherlands.

Grogan J, Barreto P, Veríssimo A. 2002. Mahogany in the Brazilian Amazon: Ecology and Perspectives on Management. Imazon, Belém, Pará, Brazil.

Hauxwell C, Mayhew JE, Newton AC. 2001. Silvicultural management of Hypsipyla spp. pp. 151-163. In Floyd RB, Hauxwell C, (eds.), International Workshop on Hypsipyla shoot borers in Meliaceae, 20-23 August 1996. ACIAR Proceedings No. 97.

Holsten EH. 1976. Life cycle of Hypsipyla grandella (Zeller). pp. 112-116. In Whitemore JL [ed.], Studies of the shootborer, Hypsipyla grandella (Zeller) Lep. Pyralidae, CATIE Misc. Publ. No. 1. CATIE, Turrialba, Costa Rica.

Horak M. 2001. Currrent status of the taxonomy of Hypsipyla Ragonot (Pyralidae: Phycitinae). pp. 151-163. In Floyd RB, Hauxwell C (eds.), International Workshop on Hypsipyla shoot borers in Meliaceae, 20-23 August 1996. ACIAR Proceedings No. 97.

Howard FW. 1991. Seasonal incidence of shoot infestation by mahogany shoot borer in Florida. Florida Entomologist 74: 150-151.

Howard FW. 1995. Reduction in damage to mahogany shoot borer and mahogany leaf miner by use of azadirachtin. Journal of Tropical Forest Science 7: 454-461.

Howard FW, Solis MA. 1989. The distribution, life history, and host plant relationships of mahogany webworm. Florida Entomologist 72: 469-477.

Howard FW, Meerow AW. 1993. Effect of mahogany shoot borer on growth of West Indies mahogany in Florida. Journal of Tropical Forest Science 6: 201-203. 
Howard FW, Gilblin-Davis R. 1997. The seasonal abundance and feeding damage of Hypsipyla grandella (Lepidoptera: Pyralidae) in seed capsules of Swietenia mahagoni in Florida. Florida Entomologist 80: 35-41.

Lamb FB. 1966. Mahogany of Tropical America. Its Ecology and Management. University of Michigan Press, Ann Arbor.

Mahroof RM, Hauxwell C, Edirisinghe JP, Watt AD, Newton AC. 2000. Effects of artificial shade on attack by the mahogany shoot borer, Hypsipyla robusta (Moore). Agricultural and Forest Entomology 4: 283.

Mayhew JE, Newton AC. 1998. The Silviculture of Mahogany. CABI Publications, Wallingford, UK.

Monte O. 1933. Hypsipyla grandella Zeller, uma praga da silvicultura (Lep. Phycitidae). Revista de Entomología (Río de Janairo) 3: 281-285.

Newton AC, Baker P, Ramnarine S, Mesén JF, Leakey RRB. 1993. The mahogany shoot borer: prospects for control. Forest Ecology and Management 57: 301-328.

Pennington TD. 1981. A monograph of the neotropical Meliaceae. New York Botanical Gardens, New York.

Ramirez Sanchez J. 1964. Investigación preliminar sobre la biología, ecología y control de Hypsipyla grandella Zeller. Boletín del Instituto Forestal Latino-Americano, Mèrida, Venezuela 16: 54-77.

Record SJ, Hess RW. 1943. Timbers of the New World. Yale University Press, New Haven, Connecticut.

Roovers M. 1971. Observaciones sobre el ciclo de vida de Hypsipyla grandella (Zeller) en Barinitas, Venezuela. Boletín del Instituto Forestal Latino-Americano de Investigación y Capacitación 38: $1-46$.

Sands DPA, Murphy ST. 2001. Prospects for biological control of Hypsipyla spp. with insect agents. pp. 121-130. In Floyd RB, Hauxwell C (eds.),
International Workshop on Hypsipyla shoot borers in Meliaceae, 20-23 August 1996. ACIAR Proceedings No. 97.

Solomon JD. 1995. Guide to insect borers of North American broadleaf trees and shrubs. Agriculture Handbook 706. US Department of Agriculture, Forest Service, Washington, DC. Speight, M. R. 2001. Discussion summary: Integrated pest management of Hypsipyla spp. p. 179. In Floyd RB, Hauxwell C (eds.), International Workshop on Hypsipyla shoot borers in Meliaceae, 20-23 August 1996. ACIAR Proceedings No. 97.

Taveras R, Hilje L, Carballo M. 2004a. Development of Hypsipyla grandella (Zeller) (Lepidoptera: Pyralidae) in response to constant temperatures. Neotropical-Entomology 33: 1-6.

Taveras R, Hilje L, Hanson P, Mexzon R. 2004b. Population trends and damage patterns of Hypsipyla grandella (Lepidoptera: Pyralidae) in a mahogany stand, in Turrialba, Costa Rica. Agricultural and Forest Entomology 6: 89-98.

Tillmanns HJ. 1964. Apuntes bibliográficos sobre Hypsipyla grandella Zeller. Boletin del Instituto Forestal Latino-Americano, Merida, Venezuela 14: 82-92.

Watt AD, Newton AC, Cornelius JP. 2001. Research in resistance of mahoganies to Hypsipyla species. pp. 89-96. In Floyd RB, Hauxwell C (eds.), International Workshop on Hypsipyla shoot borers in Meliaceae, 20-23 August 1996. ACIAR Proceedings No. 97.

Wylie FR. 2001. Control of Hypsipyla spp. shoot borers with chemical pesticides: a review. Ipp. 109-115. In Floyd. RB, Hauxwell C (eds.), International Workshop on Hypsipyla shoot borers in Meliaceae, 20-23 August 1996. ACIAR Proceedings No. 97: 109-115. 